\title{
A Spivakian Reading of Louise Erdrich's Track and Arundhati Roy's The God of Small Things
}

\author{
Behnaz Rafiee (Corresponding author) \\ Department of English Literature, Karaj Branch, Islamic Azad University \\ PO Box 31485-313, Karaj, Iran \\ E-mail: rafe385@gmali.com \\ Reza Deedari \\ Department of English Literature, Karaj Branch, Islamic Azad University \\ PO Box: 31485-313, Karaj, Iran \\ E-mail: R_deedari@yahoo.com
}

Received: 23-08-2014

Accepted: 20-10-2014

Published: 01-03-2015

doi:10.7575/aiac.ijalel.v.4n.2p.134

URL: http://dx.doi.org/10.7575/aiac.ijalel.v.4n.2p.134

\begin{abstract}
The present article is the study of Louise Erdrich's Tracks (1997) and Arundhati Roy's The God of Small Things (1988) in the light of postcolonial feminism theories of Spivak. Feminist discourse shares many similarities with post-colonial theory and for this reason the two fields have long been thought of as associative, even complimentary. "Subalternity" is a very important term in both post-colonial and feminist aspects. The word Subaltern describes the lower classes and the social groups who are at the margins of a society. Tracks and The God of Small Things depict the cultural background of their authors. Erdrich Native American culture and Roy's Indian heritage has helped them in creating certain types of female characters in their novels that still carry within themselves some features of their culture. In these novels Louise Erdrich and Roy's main focus is on the female protagonists and the specific roles they have within their communities. Although these novels depict two different cultures, there are many similarities that these two cultures share. Roy and Erdrich present several different female characters in their novels The God of Small Things and Tracks, all in different ways trapped in a system of oppression but also with a substantial degree of agency. From a postcolonial feminist perspective, Roy and Erdrich have contributed to make the representation of the subaltern women more diverse, through giving us various portraits of women that, despite their oppressed and marginalized status.
\end{abstract}

Keywords: Postcolonial Feminism, Subalternity, American culture, Indian heritage

\section{Introduction}

The present study attempts to shed light on the statements of two great authors and also to examine their beliefs and ideas in the light of Spivakian postcolonial feminism. Feminist discourse shares many similarities with post-colonial theory and for this reason the two fields have long been thought of as associative, even complimentary. "Subalternity" is a very important term in both post-colonial and feminist aspects. The aim of this study is to trace the subaltern relationship between two selected novels that represents the common problems in two different nationalities. The discussion is based on post-colonial and feminist dimensions; the emphasis is put on the notions of the "subalternity," "power," "oppression," and "resistance" in Louise Erdrich's Tracks (1997) and Arundhati

Roy's The God of Small Things (1988).

The theoretical framework applied in this article commences with a discussion about the concept of Subaltern, accompanied by a brief presentation of the postcolonial feminist approach in the analysis. Thereafter a survey of the discussions within postcolonial feminism about western feminist relationship with and representations of Third World women will follow. The chosen theoretical framework has been assessed as productive in the close reading, analysis and discussion of the characters in these novels.

Gayatri Chakravorty Spivak (1942- ) is an Indian literary theorist, philosopher and University Professor at Columbia University and "a founding member of the school's Institute for Comparative Literature and Society" (McAfee, p.16, 1989). She is famous for the essay "Can the Subaltern Speak?" this essay is considered as a founding text of Postcolonialism. She is also best known for her translation and introduction to Jacques Derrida's De la grammatologie. In 2012 she was awarded the 'Kyoto Prize' in Arts and Philosophy for being "a critical theorist and educator speaking for the humanities against intellectual colonialism in relation to the globalized world". (p.16) She received the 'Padma Bhushan', "the third highest civilian award given by the Republic of India, in 2013" (p.16). Spivak is best known for her contemporary cultural and critical theories to challenge the "legacy of colonialism" and the way readers engage with literature and culture. She often focuses on the cultural texts of those who are "marginalized" by dominant western culture: "the new immigrant, the working class, women, and other positions of the subaltern." (Spivak, p. 262. 1988) 
Louise Erdrich (1954), is an American novelist who has worked in poetry and children literature, featuring Native American characters and setting. She is one of the most prominent writers of a wave of writers known as Native American Renaissance. The novel Track (1988), written by her, follows the Anishinaabe community which was first initiated in North Dakota. It is about the community's struggle to land their traditions and beliefs and the position of their tribal society in the shifting of the U.S policies. It is set in 1920's, with the main characters, Nanapush who is a tribal elder, and Pauline Puyat, a mixed-blood member of the community and their families. It talks about epidemics with huge losses, the love which exists in the community and their resistance to cultural and political domination. Beside the mentioned issues, Pauline's bold religious asceticism becomes the main part of the story. Another matter which is highlighted in the story is Pauline's internalized racism as she even grows a hatred of her own body and her fascination with death dominates the rest of the story.

The goal of this study is to enter into the discussion surrounding Tracks by looking at the novel in terms of its contribution to the canon of Native American literature and its postcolonial Feminist aspects, specifically, Erdrich's use of different female characters. The intention here is to highlight the particular set of issues around which Tracks revolves: the loss of the tribe's land, the increasing "non-native" influences on the tribe, and the future of the tribe's traditions, belief structures and spirituality.

Arundhat Roy (1961), is an Indian author and political activist who is highly involved in environmental and human rights causes. She is the winner of 1997's Booker Prize for her first story, The God of Small Things. This book is compared to the works of Faulkner and Dickens. This is a classic work which is known worldwide. Fierce political drama is combined with forbidden love story. The plot is about an affluent Indian family changed by one fateful day in 1961.

The God of Small Things is a story about the childhood experiences of "fraternal twins whose lives are destroyed by the "Love Laws" that lay down "who should be loved, and how. And how much" (TGST, p 33, 1997). The book is a description of how the small things in life affect people's behavior and their lives. The main idea of the story is about betrayal and discrimination which exist in the country. A question always pops out as you read the story and that is "Can Anyone be Trusted." It is written in a post-colonial Anglophone theme and shows the decisive post-colonial conditions. By treatment of untouchable and female characters as the subaltern in her novel, Arundhati Roy shows their pitiable position in Indian society. The plot of The God of Small Things is mostly about a forbidden relationship between a Syrian Christian divorcee, Ammu, and a low caste carpenter, Velutha. It is a story about the rights of the women and the untouchables in traditionalist Indian society which still remains.

\section{Method}

Over the last three decades, post-colonial studies have had a deep impact upon the study and practice of feminism. Postcolonial feminist theory is based on the theories of psychoanalysis, Marxist-feminism and post-colonialism. Postcolonial feminism is a new stream of thought that primarily developed out of the work of the postcolonial theorists "who concern themselves with evaluating how different colonial and imperial relations throughout the nineteenth century have impacted the way particular cultures view themselves" (Said, p. 39, 1994). This particular tension of feminism "supports a wider viewpoint of the complex layers of oppression that exist within any given society." (Lewis, p. 47, 2003)

Postcolonial feminism began basically as a critique of both Western feminism and postcolonial theory, but later "became a burgeoning method of analysis to address key issues within both fields (Bulbeck, p.74, 1998). Unlike postcolonial theory, which focuses on the remaining impacts that colonialism has had on the current economic and political institutions of countries, postcolonial feminist theorists are interested in analyzing "why postcolonial theory fails to address issues of gender" (Mills, p. 53, 1998). Postcolonial feminism also seeks to "illuminate the tendency of Western feminist thought to apply its claims to all women around the world, when in reality the scope of feminist theory is limited" (46). By this way, postcolonial feminism tries to explain the seeming weaknesses within both postcolonial theory and within Western feminism. The concept of colonization has many different meaning within postcolonial feminist theory; "it can refer to the literal act of acquiring lands or to forms of social, political, and economic enslavement in a society"(56).

Postcolonial feminists believe that by using the term "woman" as a universal group, "women are then only defined by their gender and not by social class, race, ethnicity, or sexual preference" (Narayan, p. 37, 1997). Postcolonial feminists also work to "incorporate the ideas of indigenous and other Third World feminist movements into mainstream Western feminism" (Jayewardene, p. 232, 2008). Third World feminism follows the idea that feminism in Third World countries is not imported from the First World, "but originates from internal ideologies and socio-cultural factors" (p. 233).

\subsection{Postcolonial Feminism, Critical of Western Forms of Feminism}

Postcolonial feminism is critical of Western forms of feminism, "notably radical feminism and liberal feminism and their universalization of women's experiences" (Mills, p. 55, 1998) Postcolonial feminists argue that the experience of women in cultures impacted by colonialism is greatly different from that of women in Western countries and should be known as such. "Postcolonial feminists can be described as feminists who have reacted against both universalizing tendencies in Western feminist thought and a lack of attention to gender issues in mainstream postcolonial thought."'(p. 
Postcolonial feminism started to study the complex ways that gender interacts with other systems of "oppression and discrimination". Postcolonial feminism initiated as a criticism of the failure of Western feminism "to deal with the complexity of postcolonial feminist issues, as represented in Third World feminist movements" (p.56). The Third World feminist movement criticizes the failure of Western feminists "to recognize that not all women live in their particular political environment and location. Postcolonial feminists seek to incorporate the struggle of women in the Third World into the wider feminist movement" (p.63). Postcolonial feminists believe that Western feminist movements failed to provide a guide for women in the Third World. Postcolonial feminists do not agree that women are a universal group. "The hope of postcolonial feminists is that the wider feminist movement will incorporate these vast arrays of theories, which are aimed at reaching a cultural perspective beyond the Western world by using experiences of the feminists of the Third World" (Mills, p. 74, 1998).

Feminist postcolonial theorists are not generally unified in their reactions to postcolonial theory and Western feminism, "but as a whole, these theorists have significantly weakened the bounds of mainstream feminism, allowing it to apply to women in many different cultural contexts globally rather than focusing only on a middle-class, English-speaking woman in the developed world who is only combating patriarchy" (p.74). Postcolonial feminism works to bring the voices of Third World women to the front position and tries to shape their modern notion of feminism.

\subsection{Subaltern}

In Post-colonial theory, the word Subaltern describes the lower classes and the social groups who are at the margins of a society - "a subaltern is a person rendered without human agency, by his or her social status" (Young, p. 32, 2003). In post-colonialism the term subaltern is the social group who is "socially, politically, and geographically outside of the hegemonic power structure of the colony and of the colonial homeland" (Prakash, p. 43, 1994). In describing "history told from below", the term subaltern originated from the cultural work of Antonio Gramsci, which "identified the social groups who are excluded from a society's established structures for political representation, the means by which people have a voice in their society"(p. 56).

The terms subaltern entered the field of post-colonial studies through the works of the "Subaltern Studies Group"( Morton, p. 67, 2007), a collection of South Asian historians who investigated the "political-actor" role of the men and women who are "the mass population in the history of South Asia"(p. 67). In the 1970s, the application of subaltern began to show the colonized peoples of the South Asian Subcontinent, and described a new perspective of the history of an imperial colony, told from the point of view of the colonized man and woman, rather than from the points of view of the colonizers; in which respect, Marxist historians already had been investigating colonial history told from the perspective of the proletariat. (p.72)

The concept of the subaltern is problematic "because it remained a Eurocentric method of historical enquiry when studying the non-Western people of Africa, Asia, and the Middle East" (Prakash, p. 54, 1994). The term "subaltern" is used in the fields of "history, anthropology, sociology, human geography, and literary criticism". (p. 54)

\subsection{Strategic Essentialism}

Strategic Essentialism is a major concept in postcolonial theory that was introduced by the Indian literary critic and theorist Gayatri Chakravorty Spivak in the 1980s. "It refers to a strategy that nationalities, ethnic groups or minority groups can use to present themselves" (G. Ritze, p. 193, 2010). Although strong differences may exist between members of these groups but they continue their debates and it is "sometimes advantageous for them to temporarily "essentialize" themselves and to bring forward their group identity in a simplified way to achieve certain goals, or to oppose the levelling impact of global culture" (Ashcroft, p. 159, 2000).

Spivak has said since first introducing the term that "she is unhappy with the ways it has been taken up and used to promote essentialism itself" (G. Ritze, p. 619, 2010). The mistreatment of the concept of "strategic essentialism" is that less "scrupulous" practitioners ignore the element of strategy, and treat it as simply "a union ticket for essentialism. As to what is meant by strategy, no-one wondered about that." (p. 214) She claims to have given up on the phrase, though not the concept and in "the Boundary 2 interview", Spivak believes that, "of the two things she is best known for" (p. 4), both are often misunderstood. The first was her answer to the question "Can the Subaltern Speak?" and the second is the notion of strategic essentialism.

\section{A Spivakian Reading of Arundhati Roy's The God of Small Things}

Arundhati Roy's novel The God of Small Things won Booker Prize in 1997 and makes her "the first non-expatriate Indian author" and "first Indian woman" to win the prize, she is undoubtedly a prominent figure in literary India" (Guha, p. 42, 1982).The God of Small Things is a story about the childhood experiences of "fraternal twins whose lives are destroyed by the "Love Laws" that lay down "who should be loved, and how. And how much" (TGST, p. 33, 1997). The book is a description of how the small things in life affect people's behavior and their lives.

Set in the southern Indian state of Kerala in 1969, The God of Small Things is the story of a 7-year old girl Rahel and her twin brother Estha. The chronological setting shifts back and forth from 1969, when twins Rahel and Estha are seven years old, to 1993, when the twins are brought together at age of 31.The children live with their divorced mother Ammu. The Kerala society is described as being tradition-bound and conventional. The children soon learn that their whole life can change in a day and that love and happiness can be lost in a moment. The book is autobiographical in some parts. Arundhati Roy says in an interview (2001): 
A lot of the atmosphere in God of Small Things is based on my experiences of what it was like to grow up in Kerala. Most interestingly, it was the only place in the world where religions coincide; there's Christianity, Hinduism, Marxism and Islam and they all live together and rub each other down. When I grew up it was the Marxism that was very strong; it was like the revolution was coming next week. (Roy, p.13, 2001)

By treatment of untouchable and female characters as the subaltern in her novel, Arundhati Roy shows their pitiable position in Indian society. The plot of The God of Small Things is mostly about a forbidden relationship between a Syrian Christian divorcee, Ammu, and a low caste carpenter, Velutha. It is a story about the rights of the women and the untouchables in traditionalist Indian society which still remains.

\subsection{Untouchable and Female Characters as the Subaltern}

In The God of Small Things the term "subaltern" is placed in the southern Indian state of Kerala and it is divided chronologically between the late 1960s and the early 1990s. The plot of The God of Small Things is mainly about a forbidden relationship between a Syrian Christian divorcee, Ammu, and a low caste carpenter, Velutha. It is a story about the rights of the women and the untouchables (low cast people in India) against old restrictions imposed by the traditionalist Indian society which still remains.

Roy's novel takes place "in the context of the division of India through caste and class". As Allison Elliott points out, the origin of caste could be dated back to 1200 BCE. Caste comes from the Spanish and Portuguese word "casta" with the meaning of "race," "breed," or "lineage." there are 3,000 castes and 25,000 subcastes in India and each is related to a specific occupation. These different castes are categorized into four groups: "Brahmins--priests; Kshatryas--warriors; Vaishyas--traders; Shudras--laborers" (Elliott, p. 4, 1997). Outside the caste system are the Untouchables. They are considered polluted and not to be touched and have to marry within that caste.

In the novel, we learn that Ammu has a love affair with the Untouchable Velutha. Velutha as a Subaltern is betrayed and beaten to death by police. Similar to Velutha (who is an Untouchable), Ammu (as a female character) experiences the consequences of breaking love laws, and as a result the church refuses to bury her. From what happen to Ammu and Velutha as Subalterns in Indian Society, love laws could be seen as an "embodiment of social power/authority which convey warnings and prohibit Indian people from committing transgressive behavior" (Guha, p. 32, 1982). Many times Roy has emphasized in the novel that love laws are "the laws that lay down who should be loved, and how. And how much" (TGST, p. 33. 1997). During the story, various fears--including "the fear of being dispossessed" (p.67) and “civilization's fear of nature, men's fear of women, power's fear of powerlessness" (Dirks, p. 292, 2001)--occupy each character's mind.

As is indicated in the novel, we know that low-caste people or the so-called Untouchables as Subalterns are denied the basic human rights in many ways but Velutha, is a young man who cannot understand all these irrational rules and regulations for untouchables. He is expert in carpentry and unsuccessfully tries "to represent the changing face of India - an India which is marching on the road of progress, but all the same the India where untouchability is still practiced" (Sen, p. 56, 2005). Velutha does not approve this social discrimination. The Velutha as a subaltern in this novel wants to speak, but he is beaten to death by Inspector Mathew in police lock-up, proving the views of Gayatri Spivak expressed in her famous article, "Can the Subaltern Speak?"

\subsection{When Subaltern Resists Oppressive and Repressive Structures}

In The God of Small Things Roy emphasis on women and their rights and lacks in India by representing female characters and showing their systematic discrimination. In this novel Roy's female characters are different and similar in different ways; they do not fit into the way things are in post-colonial India.

Ammu is the most important female character in The God of Small Things. A middle class woman, she is a divorcee with two children, Eshta and Rahel. Ammu is not welcome on her return to her father's house and her brother Chacko marginalizes her. She is also surrounded by the family structure and laws among the Syrian Christian community in Kerala. Ammu is in love with untouchable laborer Velutha and breaks the "Love Laws" of their Hindu community. "Her transgression of the caste, class and religious boundaries mounts a rebellion of a kind against her marginalization as a woman" (Prasad, p. 39, 2006). Aijaz Ahmad calls her "a woman of great grit" (p. 39) her own family and society. Ammu, has to be locked up and subsequently, dies exiled. "She, as a daughter, has no claim to any property, no locus standi.”(Navarro - Tejero, p.104, 2006)

Ammu rebels against the social norms of the Syrian Christian community in Kerala. This rebellion is an act of resistance against the very foundations of this society. The act of becoming sexually involved with the "Untouchable", lower class Velutha, is an act of resistance. That is why she goes to the police station and argues against the imprisonment of this lower caste lover. A post-colonial Indian woman, who has attempted to regain her right to be an "Indian woman"

Ammu, Mammachi, Baby Kochamma and Rahel, four women in The God of Small Things, "interrogate precolonial/indigenous norms, customs, laws, values and structures connected with patriarchy, class, caste and feudalcapitalist economic structures. These women also interrogate, through all their actions, the "Love laws". "Ammu refuses to prostitute herself to the white boss of her husband. Mammachi feels threatened by whatever happens on the television. Baby Kochamma, does not accept every change in the identity of Father Mulligan. She accepts Roman Catholicism for his sake, but does not change to Hinduism. 
Roy's The God of Small Things, presents women as subalterns, some of them try to bring about change through resistance. But as subalterns they do not have the clear voice that members of other groups in Indian society have. These women support resistance against both local and global discriminations.

All the personal events in The God of Small Things are related with historical events. In this novel Roy creates a feminized space for her female characters to narrate their own stories. In this space, women create the language of their own to rebel against patriarchy/empire/the colonizer. By negotiating on the small things, Roy brings out big issues from history of India. "Roy's novel reveals to us a possibility of dismantling the western codes and performing postcolonial subversion through the process of literary decolonization." (Stanford, p. 112, 1994)

Susan Stanford believes "Roy's integration of gender and caste into the story of the nation "demonstrates how feminist geopolitics engages locationally... with power relations as they operate both on the nation and within the nation" ( $p$. 117)

\subsection{Physically and Psychologically Abused Wife}

One of the most important female character in Roy's novel The God of Small Things, is Mammachi who puts up a kind of resistance against patriarchal oppression. Mammachi is physically and psychologically abused wife like so many women in Indian society who suffer tortures and never speak out. "Roy situates Mammachi in a strategically significant position between the caste, class and gender-subalterns and the feudal-capitalist patriarchal social structures that are inflicted with age-old complexities."(Prasad, p. 67, 2006) She is not only a victim but is also the object of the jealousy of her husband. Amitabh Roy explains this issue. As Mammachi's music teacher Launsky Tieffenthal makes the mistake of informing her husband that Mammachi was "exceptionally talented" and "potentially concert class" her music lessons stop abruptly.

It was during those few months they spent in Vienna that Mammachi took her first lessons on the violin. The lessons were abruptly discontinued when Mammachi's teacher Launsky-Tieffenthal made the mistake of telling Pappachi that his wife was exceptionally talented and in his opinion, potentially concert class. (TGST, $p$. 67, 1997)

Binayak Roy in his article "The Title of The God of Small Things: A Subversive Salvo" comments on her thus: "Mammachi is another Big Woman who deifies her son Chacko and despises her daughter Ammu. When Chacko stops Pappachi's beating of Mammachi, his action has unexpected consequences: "From then onwards he became the repository of all [Mammachi's] womanly feelings. Her Man. Her only Love" (p.168, 2009)

Mammachi's tactic of applying patriarchal authority herself does not help her in the end in dealing with her son Chacko. After her husband, Chacko his son reclaims the role of the patriarch in the family He takes away the pickle-factory from her as it belongs only to the men in the family. Chacko becomes a businessman, the "Marxist" owner of the pickle factory-a capitalist enterprise.

Chacko was a self-proclaimed Marxist. He would call pretty women who worked in the factory to his room, and on the pretext of lecturing them on labor rights and trade union law, flirt with them outrageously. He would call them Comrade, and insist that they call him Comrade Back (which made them giggle). Much to their embarrassment and Mammachi's dismay, he forced them to sit at table with him and drink tea. (TGST, p. 31, 1997)

Amitabh Roy comments: "Thus, despite his professed Marxism, Chacko follows Manu and the tradition in asserting the son's domination over mother in old age. Mammachi submits to it as such ideas are so familiar to her."(p.67, 2005) Mammchi becomes a device of patriarchal power in spite of being a victim herself. As a post-colonial Indian woman she gives way to pre-colonial caste rules and "Love laws" and at the same time tries to be in an questioning mode concerning both the colonial past as well as the neo-colonial present in her interactions with her daughter Ammu.

Mammachi's daughter Ammu resists patriarchy and caste and class narrow-mindedness in public and pays with her life. Although both her children are divorcees, Mammachi does not resist her dictator son. Mammachi does not tolerate the mutual relation between Ammu and Velutha because of cast and class. Mammachi's objection against Velutha supports his murder in the hands of the police. Velutha being the subaltern meets death and becomes the god of small things. But Mammachi's family faces disaster.

Mammachi continues to hold on to her dominating role misrepresenting the idea that women should only obey orders. As a post-colonial Indian woman she is fragmented by the pulls of pre-colonial tradition. Although, Mammachi gives way to these forces reader retain sympathy for her for the damages she had to suffer in life.

\section{A Spivakian Reading of Louise Erdrich's Tracks}

Award-winning author Louise Erdrich characters are men and women of white, Indian and mixed blood heritage and their history of alienation and outlandish experience in the home country. Indian reservation in North Dakota between the winter of 1912 and the spring of 1924. Tracks is the story of Fleur Pillager told by Nanapush, an Ojibway tribe elder, and Pauline, a young mix-blood woman who lives with her aunt Regina and Dutch. Pauline, who is suspicious of Fleur and her magical powers, works with Fleur in a butcher shop in Argus. Pauline is fascinated by Fleur's strong personality. Fleur is the only one of her family to survive when an epidemic hits the reservation. She is rescued by Nanapush who has lost his own family, and so considers Fleur as his daughter. She is considered bad luck by reservation people. She goes to live in her family's cabin on Mitchimanitou Lake. The people believe she keeps a sea monster in the lake under control. She visits the murderer shop in town, and joins the men there in playing cards. The 
men become very angry when Fleur plays so well she takes all their winnings. A tornado strikes shortly after this. The men are found mysteriously locked into a meat locker from the outside. Only one survives, and he is disabled. This adds to even more fear of Fleur among the reservation people.

Eli Kapshaw falls in love with her, and will not be discouraged by the fears and stories. He asks Nanapush's help in winning her heart. He moves into her cabin, and they have a baby. Fleur almost dies giving birth. A drunk bear comes into the cabin, and frightens her into pushing the baby out. Because Eli is away seeking help, and Fleur is unconscious, Nanapush is forced to name the baby. He calls her Lulu Nanapush after his own dead child.

Fleur, her family, and community struggle through the epidemics that sweep the tribe, starvation starts from poor government facilities, and because of their inability to pay government taxes they lose their lands. Fleur is betrayed by her in-laws when they take the money that was supposed to pay for her land as well as theirs, and use it entirely on their own debt. Fleur loses her confidence, and sends her daughter Lulu away to a government school. She waits until the last trees are crashing down around her house before she takes off from the reservation. Nanapush is successful in getting Lulu out of the government school. He tells her mother's story so that she can understand her past, and hopefully not get into a bad marriage. Peterson believes by this story "Erdrich insists on the need for the tribal people to tell their stories and their own histories." (P. 985, 1994)

\subsection{A Female with Masculine Characteristics is Considered as an Other}

According to Oxford advanced Learner's Dictionary (2005), the term 'Other' is "used to refer to people or things that are additional or different to people or things that have been mentioned or are known about"(p.897, 2005).Charles E. Bressler in his Literary Criticism asserts that, "Other is a term used in feminist criticism (the 'non-male' and thus unimportant) and in postcolonialism (the colonized) to mean 'different from' and unimportant, that which is dominated"(p. 353, 2007).

Fleur as an Other, because of her family heritage is depicted throughout the novel, to have a distinctive strength. She is of a Pillager tribe who was famous for "the secret ways to cure or kill," (Tracks, p.2, 1989) or for possessing the power which "travels in the bloodline, handed out before birth" (p. 31). When she was seventeen Her family died of consumption, leaving her alone, but Fleur "was wild as a filthy wolf, a big bony girl whose sudden bursts of strength and snarling cries terrified the listening Pukwan"(p. 3). Fleur, is orphaned from a young age and dependent only on herself and her abilities. There is something special about Fleur and when she is grown up, people fear her but at the same time respect her for her enormous strength and power. Nevertheless, they notice only her appearance, not her soul. Fleur's "cheeks were wide and flat, her hands large, chapped, muscular. [Her] shoulders were broad and curved as a yoke, her hips fishlike, slippery, and narrow. An old green dress clung to her waist, worn thin where she sat" (p. 18).

Her way of walking and behaving is similar to the men's behavior. She is as strong as them because she "could lift a haunch or carry a pole of sausages without stumbling" (p. 16). Other times she also dresses like a man. In Native American culture, a common term for people who either have the qualities and behavior of the opposite sex is a berdache. According to Charles Callender and Lee M. Kochens, a berdache is "person usually [but not exclusively] male who was anatomically male, who was anatomically normal but assumed the dress, occupations and behavior of the other sex to effect a change in their gender status" (qtd. in Barak, p.8, 2008). In a way, Fleur can be viewed as a symbolic berdache. Because of her masculine characteristics such as her strength or not being afraid of non-Native American male authority or beating men at cards.

In "Gender Mixing," Julie Barak summarizes the anthropologists' view about female berdaches who were considered as"manly-hearted women." These women had special qualities such as "aggressiveness, independence, ambition, boldness, and pronounced sexuality” (qtd. in Barak, p. 8, 2008). Moreover, as Barak points out:

Manly-hearted women are reputed to be ikitaki-passionate women [whose] sexual unconventionalities are subject of much gossip." In the case of Fleur, every man observes that it is dangerous to tangle with Fleur because she "definitely knows how to handle men as she swayed them, sotted them, made them curious about her habits, drew them close (p.16).

Fleur is aware of her feminine beauty and the ability to attract men. This fact causes much gossip among the women in her community as they perceive Fleur as a witch who draws men away, either curses them or kills them. She "messe [s] with evil, laughe [s] at the old women's advice [...] [and] [gets] herself into some half-forgotten medicine, studie [s] ways we shouldn't talk about" (Tracks, p. 12, 1989). No one notices that Fleur's "fifth toes [are] missing," that she has "sly brown eyes" or that her teeth are "strong and sharp and very white" (18). This Fleur's abnormality of not having fifth toes could be perceived as a mark of someone who possesses supernatural abilities.

\subsection{Fleur's Final Quest for her True Identity and Reconnections to her Ancestors}

Although Fleur has the abilities to heal, sometimes she cannot help herself and is dependent on the help of others. Fleur has struggled over the years to get what she has always wanted, though, she has paid a high prize for her purpose. The loss of her two children, being sent out to a boarding school, latter dying during the delivery, has left deep marks in Fleur's heart. Her alienation from her people and her former life has also influenced her as she has often "missed getting her own meat and medicines, catching her own fish, snaring rabbits and looping the necks of roosting partridge" (Tracks, p. 27, 1989).

Fleur also realizes that by abandoning her first child she has failed as a mother to perform her function. Although she is a mother, she does not connect with her children and there is a spiritual emptiness that she feels deeply in her heart. All 
these elements leads to Fleur's inner weakening that Margaret and Nanapush notice. In this case, Fleur is wounded in her heart and her soul, and consequently she needs the spiritual healing to be recovered by.

By seeing the emptiness in Fleur's eyes, Margaret decides to help her by bathing her. The bathing has a special place in Chippewa culture as it serves as "a purifying preludes to ceremonies and as curatives in their own right" (Vecsey, p. 151, 1983). Margaret recognizes the significance of Fleur's washing as it reflects the Fleur's spiritual state: "Fleur Pillager stood naked by the washtub, her hair down her back again but not so long as it was before" (Tracks, p. 202, 1989).

Fleur's standing naked, without her clothes, "mirrors in a way the core of her soul that is preparing to be washed, molded, shaped and reshaped again, so it can reach the final state."(p.151) Fleur distinguishes that this washing is only the beginning of her journey that she is going to take in order to recover herself. Margaret starts to wash Fleur's body, describing every detail:

I used the copper dipper to pour the water over her. [...] I wet her hair and soaped it, then rinsed every trace of soap from her hair and did the whole thing again. [...] I cleaned her face with a rag, washed her carefully, dabbing the cloth with great care around the beautiful shape of her eyes. I traced the curve of her ears, ran the rag down her neck then back up under her chin. I took her hand in mine, and then I washed up and down each arm. I washed each finger and polished each clear oval nail. Then I had her kneel in the tub as I scrubbed her lean back. (Tracks, p. 202-3, 1989)

This purgation by washing is significant as it prepares Fleur for the final purification - the purification of her soul. During her purification Fleur realizes the mistakes she has made, concerning her children, her alienation from her family and her own roots. Over the years, all the unseen and unheard emotions have been collected and it is only now that Fleur fully expresses her sorrow and her regrets by uncontrolled crying: "Racking sobs built and died in her, violent and unashamed" (Tracks, p. 203, 1989).

Tracks, like much contemporary Native American fiction, is a novel concerned with the search and maintenance of, identity. After the American Revolution, as Joy Porter notes, “American Indians were systematically destroyed, if not physically, then culturally and spiritually, when "Americans created a national mythology that consigned Indians to a "savage" past" (p. 50).

\subsection{Flour's Resistance}

Tracks is the story of a woman who tries to maintain the traditional ways, but finally loses her land to the timber companies and sends her daughter Lulu to the Bureau of Indian Affairs boarding school. In cultural terms, this challenge depicts the political battles of many American Indian over the issue of identity during the 1970s with the rise of the American Indian Movement (AIM). "This is the cultural, political, and biographic matrix out of which Tracks merges in its first form during the late 1970s and early 1980s"(Stanford, p 107, 1994).

Fleur the female character of the story belongs to the Pillager family who were not converted to Catholicism and were consequently condemned of witchery. The Pillagers "knew the secret way to cure or kill" (Tracks, p. 2, 1989). Fleur "dressed like a man" and is therefore associated with supernatural horror:

Some say she kept the finger of a child in her pocket and ... she laid the heart of an owl, on her tongue so she could see at night, and went out hunting, not even in her own body. We know for sure because the next morning, in the snow or dust, we followed the tracks of her bare feet and saw where they changed, where the claws sprang out, the pad broadened and pressed into the dirt. By night we heard her chuffing cough, the bear cough. (p.12)

The natives accuse Fleur of being the beloved of Machimanito the water monster or that she is the embodiment of the animal spirit. Pauline uses the pronoun "we" to identify with the town and at the same time cast Fleur as "other". This is a primary step that finally leads to decision about throwing her out of the reservation before Fleur decides to leave.

The body of Fleur and her beauty is the cause of many jealousy and hostility. She is physically very attractive and her beauty is compared with Pauline's ugliness. The rape scene is inspired by prejudice against Fleur as a woman. They "only saw her in the flesh" (Tracks, p. 18, 1989) and "could not believe, first of all that a woman could be smart enough to play cards (p. 21).

In many parts of the story Fleur uses her power "to kill" her enemies. In various occasions, Fleur fights colonialism face to face, expressing her shamanistic energy "to kill." The quarantine police official Pukwan goes home, "crawl[ing] into bed, and [taking] no food from the moment until his last breath [passes]" (p. 4). The tax agent, who asks Fleur for money, ends up "living in the woods and eating roots, gambling with ghosts" (p. 9). George Many "Women, who guides the White mappers into the woods, dies in an unexpected drowning" (p.11). All this symbolizes her anger and resistance.

Despite the fact Nanapush describes and celebrates Fleur's resistance against the White colonization, Fleur in the end loses her land to the White lumber companies. Near the end of the novel, as "her vision is obscured, [and] her Manitou helper [sleeps] deep in the lake," Fleur vanishes "without leaving tracks" (Tracks, p. 215, 1989), this image suggests her disappearance and, along with it, the disappearance of the pure Anishinabe culture she symbolizes. "A tribe of pressed trees. A tribe of chicken-scratch that can be scattered by a wind, diminished to ashes by one struck match" (p. 225). Nanapush as a witness to Anishinabe loss, narrates the destructive power of White Native Americans. 


\section{Conclusion}

In The God of Small Things and Tracks, Louise Erdrich and Roy's main focus is on the female protagonists and the specific roles they have within their communities. Although these novels depict two different cultures, there are many similarities that these two cultures share. Roy and Erdrich present several different female characters in their novels The God of Small Things and Tracks, all in different ways trapped in a system of oppression but also with a substantial degree of agency.

From a postcolonial feminist perspective, Roy and Erdrich have contributed to make the representation of the subaltern women more diverse, through giving us various portraits of women that, despite their oppressed and marginalized status, are not depicted without agency or responsibility. For example Fleur as a female character and protagonist of the Tracks has struggled over the years to get what she has always wanted, though, she has paid a high prize for her purpose. The loss of her two children, being sent out to a boarding school, latter dying during the delivery, has left deep marks in Fleur's heart. Similar to Fleur, Ammu the Female character of The God of Small Things rebels against the social norms of the Syrian Christian community in Kerala. This rebellion is an act of resistance against the very foundations of this society. The act of becoming sexually involved with the "Untouchable", lower class Velutha, is an act of resistance. That is why she goes to the police station and argues against the imprisonment of this lower caste lover, Ammu as an Indian woman, who has attempted to regain her right to be an "Indian woman", is treated as an outcast in her own family and society. Ammu, has to be locked up and subsequently, dies exiled.

Briefly Ammu and Fleur as subaltern/women try to resists oppressive and repressive social and political structures. Although they may not consciously have worked for other subalterns but their actions contribute to the freedom of different kinds of subalterns. They do not succeed in making any change but put up a brave fight for realizing their dreams.

These two novels also reflects the contemporary arguments surrounding Postcolonial studies and, more specifically, highlights the division between those who wish to maintain the traditions of their communities and those who are beginning to fit into "western" culture. For example Pauline in Tracks does not want to be Indian; she wants to be white and makes the decision of converting to Catholicism. This mixed blood character that appears in this novel exists to highlight the protagonist lost between cultures and identities. Pauline is an example of a character deeply in struggle between understanding and acceptance of her tribal identity and the full absorption into white culture.

Erdrich uses Pauline's character to show this identity struggle as she becomes more and more detached from the tribe, finally transforming into Catholic nun Leopolda by the novel's end. Similar to Pauline Baby Kochamma in The God of Small Things is in her youth quite rebellious in the sense that she both opposes the tradition of arranged marriages by autonomously choosing a man, and then even converting to Catholicism against her father's will. Pauline in Tracks and Baby in The God of Small Things are examples of those who are beginning to fit into "western" culture. But Nanapush and Margaret in Tracks and Mammachi in The God of Small Things are between those who wish to maintain the traditions of their communities. Although they follow the new ways of the white world but at the same time maintain their original culture.

Lulu in Tracks and Rahel in The God of Small Things as the representation of the third generation female characters, want to change norms, customs, laws, values and structures connected with patriarchy, class, caste and feudal-capitalist economic structures. The most important act by Rahel is her love for her twin brother, Estha.

So, Ammu, Mammachi, Baby Kochamma and Rahel, four women in The God of Small Things, and Fluer, Pauline, Margaret and Lulu in Tracks try to bring about change through resistance. But as subalterns they do not have the clear voice that members of other groups in society have. These women support resistance against both local and global discriminations. In the spirit of strategic essentialism, Roy and Erdrich have ventured to give voice to some of those who are seldom referred to in the official history writing of Literature. All the personal events in The God of Small Things and Tracks are related with historical events. In these novels Roy and Erdrich creates a feminized space for their female characters to narrate their own stories

In this The God of Small Things and Tracks Roy and Erdrich depicts the ways superior class of society are suppressing and declining the rights of the lower class, and the way males are trying to suppress women. It seems that in these novels by depicting the misery of Subaltern, authors are trying to say the fact that it is time that the subaltern get a chance to speak, and it is then that we can call it a truly post-colonial era.

Note: TGST Stands for The God of Small Things

\section{References}

Ashcroft, B., Griffiths, G., and Tiffen. N. (2000). Post-colonial Studies: The Key Concepts. London: Routledge.

Barak, J. (2008). Blurs, Blends, Berdaches: Gender Mixing in the Novels of Louise Erdrich. Studies in American Indian Literature 8.3 (1996). 17 Feb.

Bulbeck, C. (1998). Re-Orienting Western Feminisms: Women's Diversity in a Postcolonial World. New York: Cambridge University Press. 
Bressler, C. (2007). Literary Criticism, New Jersey: Pearson Prentice Hall.

Dirks, Nicholas B. (2001). Castes of Mind: Colonialism and the Making of Modern India. Princeton and Oxford: Princeton UP.

Elliott, A. (1997). Caste and The God of Small Things. english.emory, Fall 1997.

$<$ http://www.english.emory.edu/Bahri/caste.html $>$.

Erdrich, L. (1989).Tracks. Vol. 3. New York: HarperCollins.

Guha, R. (1982). Subaltern Studies: Writings on South Asian History and Society, New Delhi: Oxford University Press.

G. Ritze/J. M. R. (2010). eds, the Concise Encyclopedia of Sociology. New Yourk: Palgrave Macmillan.

Hornby, A.S, and Wehmeier, S. (2005). Oxford Advanced Learner's Dictionary. New York: Oxford University Press.

Jayawardena, Ki. (2008). Feminism and nationalism in the Third World. New Delhi: Kali.

Lewis, R \& Mills, S. (2003). Feminist Postcolonial Theory: A Reader. New York: Routledge.

McAfee, R. Preston, and McMillan, J. (1989). Government Procurement and International Trade. Journal of International Economics, 263(1), 291-308.

Mills, S., Stevi, J., and Jackie J. ed. (1998). Contemporary Feminist Theories. Edinburgh: Edinburgh University Press.

Morton, S. (2007). "The Subaltern: Genealogy of a Concept”, in Gayatri Spivak: Ethics, Subalternity and the Critique of Postcolonial Reason. Malden, MA: Polity. pp. 96-97

Navarro-Tejero, A. (2006). Power Relationships in The God of Small Things. Delhi: Pencraft International.

Narayan, U. (1997). Dislocating Cultures: Identities, Traditions, and Third World Feminism. New York and London: Routledge.

Peterson, N. (1994). History, "Postmodernism, and Louise Erdrich's Tracks." Modern Language Association. PMLA, Vol. 109, No. 5 (Oct., 1994), pp. 982-994

Roy, A. (1997). The God of Small Things, New Delhi: India Ink.

----. (2001). Power Politics, 2nd ed. (Cambridge Mass: South End Press, p.13.

Roy, A. (2005). The God of Small Things: A novel of social commitment. New Delhi, India: Atlantic Publishers and Distributors.

Roy, B. (2009). The Title of The God of Small Things: A subversive salvo. ANQ, 22(3), 56-63

Said, E. (1994). Culture and Imperialism. London: Random House.

Sen, A. (2005). The Argumentative Indian: Writings on Indian History, Culture and Identity. London: Penguin.

Spivak, G. (1988). Can the subaltern speak? Marxism and the Interpretation of Culture. Oxford: Oxford University Press. 271-313

---. (1996). "Reading Spivak". The Spivak reader: selected works of Gayatri Chakravorty Spivak. Routledge. pp. 1-4.

Stanford, S. (1994). Identity Politics, Syncretism, Catholicism, And Religion In Louise Edrich's Tracks. Religion \& Literature, 26(1).

Prakash, G. (1994). "Subaltern Studies as Postcolonial Criticism”, The American Historical Review, December, Vol. 99 , No. 5, 1475-1490, 1476.

Prasad, M. (2006). Arundhati Roy: Critical Perspectives. First ed. Delhi: Pencraft International

Vecsey, C. (1983).Traditional Ojibwa Religion and Historical Changes. Philadelphia:Dianne.

Young, R. (2003). Post colonialism. Oxford: Oxford university press. 